\title{
Combining monetary policy and prudential regulation: An agent-based modeling approach
}

\author{
Michel Alexandre (BACEN) \\ Gilberto Tadeu Lima (FEA/USP)
}

\begin{abstract}
:
The aim of this paper is to study the interaction between monetary policy and prudential regulation in an agent-based modeling framework. Several relevant policy implications are drawn from this analysis. First, the implementation of a cyclical capital component as proposed in Basel III loses its efficacy when combined with some interest rate rules. Second, interest rate smoothing is more effective than the other interest rate rules assessed, as it outperforms them concerning financial stability and performs as well as them regarding macroeconomic stability. Finally, there is no long-run tradeoff between macroeconomic and financial stability regarding the assessed parameters.

\section{Resumo:}

O objetivo deste trabalho é estudar a interação entre política monetária e regulação prudencial em um modelo baseado em agentes. Várias implicações relevantes relativas a política econômica emergem desta análise. Primeiro, a implementação de um componente cíclico de capital, tal como proposto em Basileia III, perde sua eficácia quando combinado com algumas regras de taxas de juros. Segundo, o smoothing da taxa de juros mostrou-se mais efetivo que outras regras de taxas de juros, já que supera as mesmas relativamente a estabilidade financeira e é tão eficaz quanto as demais no que tange a estabilidade macroeconômica. Finalmente, não há um trade-off entre estabilidade macroeconômica e financeira relativamente aos parâmetros avaliados.
\end{abstract}

Keywords: Agent-based modeling, monetary policy, prudential regulation.

Palavras-chave: Modelo baseado em agentes, política monetária, regulação prudencial.

JEL Classification: E52; G18; C63.

Área ANPEC: 4 - Macroeconomia, Economia Monetária e Finanças. 


\section{Introduction}

The 2008 financial crisis promoted a revival of the debate on the interaction between the real and financial sectors. Although some arguments, as the financial accelerator proposed by Bernanke and Gertler (1995), had already pointed out the existence of transmission channels from one sector to another, the crisis suggested that such interlinks could be much more complex than initially thought. It left clear that small disturbances in one sector, through essentially nonlinear relationships, could be amplified and spread across both. Indeed, although the turmoil had its roots in U.S. subprime crisis, it has crossed the border of the financial sector, bringing heavy losses to the real economy.

Before the crisis, the reigning view concerning macroeconomic policy was that monetary policy and prudential regulation could pursue their goals - macroeconomic and financial stability, respectively acting independently, without any need of coordination. According to this dominant paradigm, a monetary policy based on inflation targeting and flexible exchange rates and a financial regulation grounded on microprudential measures would accomplish their objectives (Canuto and Cavallari, 2013).

More recently, the balance started to be tipped in favor of a more harmonious interaction between monetary policy and prudential regulation. In fact, through linkages between real and financial variables, one policy may affect the other's target, sometimes in an undesirable way. For instance, by pursuing macroeconomic stabilization in a recession scenario, monetary policy may reduce the interest rate. However, low interest rates may lead to less banks' incentive to monitor borrowers, over-leverage in banks and the bearing of higher risks by agents in order to achieve higher returns, bringing threats to financial stability (IMF, 2013). Hence, the stand-alone execution of policies may lead to unsatisfactory outcomes.

To handle this issue of policy coordination, existing macroeconomic models should be endowed with an attribute which proved to be important in the last crisis: the ability to tackle with nonlinear interdependencies between real and financial variables. In the case of Dynamic Stochastic General Equilibrium (DSGE)-type models, the main workhorse of most central banks, this is done through the incorporation of financial frictions (BCBS, 2012). This allows the study of optimal combinations between monetary policy and prudential regulation within the DSGE framework, as has been done recently by some researchers (e.g., Agénor et al., 2013; Beau et al., 2011; Goodhart et al., 2013; Lambertini et al., 2013).

Nonetheless, DSGE models have some inherent characteristics which limit their usefulness to the assessment of policy actions. As discussed above, a key element to grasp the occurrence of crashes is the understanding of nonlinear feedbacks among financial and real variables. Nevertheless, the incorporation of nonlinearities in DSGE models is quite limited, as they are usually solved through log-linearization around a unique steady state. Furthermore, the embodying of some endogenous elements responsible for the propagation of the crisis, as irrational behavior and inefficient markets, is hard in DSGE models, due to their assumption of forward-looking rational behavior (Canuto and Cavallari, 2013). Indeed, in these models, the risk is brought in by exogenous shocks. Additionally, the hypothesis of perfect rationality and optimizing behavior is even more unrealistic during crisis, as these abilities depend on historical relationships which no longer hold (Bookstaber, 2012).

Another strategy has been the development of new approaches. One of the most promising alternative approaches is the Agent Based (AB) modeling. ${ }^{1}$ AB modeling conceives the economy as a complex system, defined by the presence of emergent properties, that is, an aggregate behavior remarkably distinct from the simple extrapolation of units' behavior (Krugman, 1996). In the AB modeling framework, agents (consumers, firms etc.) are rationally limited computational entities. They interact with each other following simple behavioral rules, giving rise to nonlinear patterns. Such rules, grounded on incentives and information, may evolve according to their fitness - the payoff they provide to the agents adopting them. In this case, the model is called evolutionary. Once the initial conditions and parameters of the model are established, the modeler can observe how the system evolves over time.

\footnotetext{
${ }^{1} \mathrm{By} \mathrm{AB}$ models we are referring to computational agent-based models. There are also models of heterogeneous interacting agents, solvable analytically through technics coming from statistical physics or Markov chains (Gallegatti and Kirman, 2012).
} 
AB models have some advantages over DSGE models regarding the assessment of economic policy. According to Fagiolo and Roventini (2012), such advantages belong to two classes: theory and empirics. From the theoretical point of view, as they are not a priori required to be analytically solvable, they allow the relaxing of several simplifying assumptions (e.g., equilibrium and rational expectations) necessary to mathematical tractability. Their disengagement from analytical solvability makes them cope with nonlinearities much better than DSGE models. This flexibility is the base of their empirical advantage; it enables them to be much more realistic than DSGE models in the case of inputs (assumptions more similar to the observed ones), as well as concerning the outputs (replication of stylized facts of interest).

Policy experiments with $\mathrm{AB}$ models are typically done in the following way. First, the $\mathrm{AB}$ model is designed to reproduce relevant stylized facts of the policy target (e.g., price level). Then, it is gauged how the implementation or changes in some policy parameter (e.g., interest rate) impact the behavior of such variable (Fagiolo and Rovetini, 2012). The possibility of implementing a wide range of policy measures turns $\mathrm{AB}$ modeling very attractive for the performance of policy exercises, as has been done extensively in recent years. ${ }^{2}$

The aim of this paper is to study the interaction between monetary policy and prudential regulation in an $\mathrm{AB}$ modeling framework. In the model proposed here, firms borrow funds from the banking system in an economy regulated by a central bank. The central bank is responsible for carrying out monetary policy, by setting the interest rate, and banking prudential regulation. Among the multiple tools available for prudential regulation, we deal with a specific one in this paper, namely, the capital requirement through the setting of a cyclical buffer. Different combinations of interest rate and capital requirement rules are carefully evaluated regarding macroeconomic and financial stability. The former depends negatively on output and price volatility and the latter is measured by the bad debt-to-credit ratio. While monetary policy employs Taylor-type interest rate rules, the capital requirement rules involve the establishment of a cyclical component, as proposed in the Basel III agreement. In the end, our purpose is to gain qualitative insights on the suitable combinations between monetary policy and prudential regulation.

$\mathrm{AB}$ modeling has been extensively applied by researchers to analyze the impacts of monetary policy on the economy. Usually, effects of monetary policy are explored through changes in the interest rate, as in Dosi et al. (2012). In some studies (Delli Gatti et al., 2005; Raberto et al., 2008; Mandel et al., 2010), such changes are driven by Taylor-type rules. Prudential regulation has also been the object of study of AB models. Teglio et al. (2012) and Cincotti et al. (2012) study the impact of capital requirement rules on the economy employing the EURACE model ${ }^{3}$. Krug et al. (2014) developed a stock-flow consistent $\mathrm{AB}$ model to assess the effects of the main components of Basel III on financial stability. Nonetheless, as far as we know, no available study is devoted to test different combinations of monetary policy and prudential regulation within the AB modeling framework. Similar exercises were conducted mainly through the use of DSGE models, as referenced above. A noteworthy exception is Barnea et al. (2015), which developed an overlapping-generations model to analyze the interaction between these policies. However, we believe that AB models, due to their greater flexibility to cope with nonlinearities, can shed new and relevant light on this issue.

In addition to this introduction, this paper has more four parts. Section 2 outlines the model, while results of simulations concerning the baseline case are shown in Section 3. Meanwhile, Section 4 contains an assessment of various combinations of monetary policy and prudential regulation, considering their performance regarding both macroeconomic and financial stability. Concluding remarks are presented in the last section.

\section{Structure of the model}

\footnotetext{
${ }^{2}$ See the excellent review in Fagiolo and Roventini (2012).

${ }^{3}$ EURACE is a large-scale, multi-sector agent-based model and simulator, which is under development since 2006 within an EU-funded research grant (Cincotti et al., 2011).
} 
The model is composed by three groups of agents: firms, which produce consumption goods, the banking system, which provides credit to firms and receive deposits from firms and firm-owners, and the central bank, which is in charge of setting the base interest rate and the capital requirement ratio.

This model has several ingredients of other models, such as Delli Gatti et al. (2010) and Dosi et al. (2013), in addition to several novel features. Indeed, our purpose is not to contribute methodologically to the literature on the agent-based economic modeling framework, but rather to explore a specific issue (the coordination between monetary policy and prudential regulation) within such framework. The main feature of the model herein is the supply/demand mutual restriction. An individual firm's sales are a fraction of aggregate demand, but constrained by its own production. Hence, an individual firm's output can be equal, lower (engendering unfilled demand) or higher (engendering unsold production) than the firm's share in aggregate demand. It is supposed that firms operate in an imperfect information environment, which allows them to set different prices. Market shares are a function of the corresponding markups: firms setting relatively lower markups increase their market share. Firms with negative net worth are expelled from the model, and any bankrupt firm is replaced by a new one.

On the financial side, firms' demand for credit with the banking system follows the "dynamic trade-off theory" proposed by Riccetti et al. (2013), meaning that firms have a long-run leverage target. Firms' credit demand is fulfilled following a pecking order according to their net worth. The banking system sets a different interest rate to each firm according to its own soundness and the firm's leverage level.

As it turns out, there is interdependence among the individual firms' financial robustness. It operates through two channels. The first one is the banking credit. If a firm goes bankrupt, the banking system's net worth shrinks. As the maximum total credit is a multiple of the banking system's net worth, the available credit will be lower in the next period, thus eventually preventing other firms from producing more. The second such channel is a demand externality. By producing less, firms reduce aggregate demand, thus affecting the other firms' revenues and profits.

The following subsections detail the behavior of each component of the model.

\subsection{Accounting identities}

There is an aggregate consistency between assets, liabilities and financial resources circulating among the components of the model. Firms' liabilities are composed by net worth, NW, and loans, B. Firms' asset is capital, $\mathrm{K}$. The banking system has, in the liability side, net worth, $\mathrm{NW}^{\mathrm{B}}$, and deposits, $\mathrm{D}$, while its assets are formed by loans, B, and voluntary, non-remunerated, reserves kept at the central bank, R. Firm-owners receive a fraction of profits as dividends, A. As in Delli Gatti and Desiderio (2014), we assume that there is no currency in the model, with all funds taking the form of inside money. Firms deposit their net worth at the banking system and firm-owners' dividends totalize their deposits in the banking system, $D^{K}$. Loans come back to the banking system as new deposits. The aggregate equality between assets and liabilities implies that $R=N W+N W^{B}$. All these accounting relationships are represented in Table 1.

The flow of nominal funds is displayed in Table 2. The aggregate wage bill, $w L$, where $\mathrm{w}$ is nominal wage and $\mathrm{L}$ is hired labor, is paid by firms and received by workers. A share of nominal profits is received by firm-owners as dividends. Nominal debt commitments, $i B$, where $i$ is the nominal interest rate, flow from firms to the banking system. Nominal output, $p Y$, where $\mathrm{p}$ is the price level and $\mathrm{Y}$ is the real output, is consumed by workers and firm-owners or stored.

\subsection{Firms}

A large number of firms, indexed by $\mathrm{i}=1, \ldots, \mathrm{N}$, produce a consumption good using labor and capital. It is assumed that firms operate under conditions of imperfect information in order to allow for price heterogeneity. ${ }^{4}$ The output of each firm $Y_{i, t}$ is determined by the following expression:

\footnotetext{
${ }^{4}$ On consumers' imperfect price knowledge, see, for instance, Rotemberg (2008).
} 


$$
Y_{i, t}=\min \left(\alpha K_{i, t}^{\beta}, L_{i, t}\right)
$$

where $\alpha>0$ and $0<\beta<1$ are fixed (and uniform across firms) parameters, $K_{i, t}$ is the capital stock of firm $\mathrm{i}$ at period $\mathrm{t}$ and $L_{i, t}$ is the corresponding hired labor. It can be seen that labor productivity is normalized to one. For the sake of simplicity, we also abstract from the presence of physical capital, as we consider that $K$ is simply credit capital. Consequently, capital comprises the stock of loans granted to the individual firm, $B_{i, t}^{S}$, and its net worth, $N W_{i, t}$ :

$$
K_{i, t}=B_{i, t}^{S}+N W_{i, t}
$$

Debt lasts for $t_{D}$ periods. Therefore, the stock of debt is the sum of the flow of debts in the last $t_{D}$ periods: $B_{i, t}^{S}=\sum_{t-t_{D}+1}^{t} B_{i, t}^{F}$. More details on how credit demand of firms is met will be given in the next section.

There is a perfectly elastic supply of labor so an individual firm can hire as much labor as it wants at the current wage. Considering (1), a firm will hire a quantity of labor given by $\alpha K_{i, t}^{\beta}$. It is assumed that the labor contract signed by firms and workers establish a minimum real wage. Therefore, there is a reasonable limit to the possibility that financially fragile firms improve their financial situation as a result of a sharp decline in real wage costs (recall that labor productivity is constant). The real wage, $w_{t} / p_{t}$, where $w_{t}$ is nominal wage and $p_{t}$ is the price level, has as lower bound a fraction $\psi<1$ of the initial real wage, $w_{0} / p_{0}$. Therefore, the nominal wage, which is uniform across firms, is given by:

$$
w_{t}=\left\{\begin{array}{ccc}
w_{t-1} & \text { if } & \frac{w_{t-1}}{p_{t-1}}>\psi\left(\frac{w_{0}}{p_{0}}\right) \\
\psi p_{t-1}\left(\frac{w_{0}}{p_{0}}\right) & \text { if } & \frac{w_{t-1}}{p_{t-1}} \leq \psi\left(\frac{w_{0}}{p_{0}}\right)
\end{array}\right.
$$

The nominal revenue of firm $\mathrm{i}$ at period $\mathrm{t}$ corresponds to a share $s_{i, t}$ of the aggregate nominal demand, $C_{t}$ :

$$
C_{t}=w_{t} L_{t}+\delta \pi_{t-1}
$$

In the equation above, $w_{t} L_{t}$ is the aggregate wage bill paid by the firms, $\delta$ is the (constant) fraction of profits paid by the firm to its owner as dividends, which is uniform across firms, and $\pi$ is the aggregate nominal profit of firms. Thus, we assume that workers consume all their income and firmowners' dividends are saved to be entirely spent in the next period.

The nominal profit of an individual firm is given by:

$$
\pi_{i, t}=\min \left(p_{i, t} Y_{i, t}, s_{i, t} C_{t}\right)-w_{t} L_{i, t}-i_{i, t} B_{i, t}^{S}
$$

The first term of the expression above is the firm's revenue. It corresponds to its share, $s_{i, t}$, of the aggregate demand, but it cannot be greater than its nominal production. Unsold production corresponds to inventories, $I_{i, t}=\max \left(0, p_{i, t} Y_{i, t}-s_{i, t} C_{t}\right)$. Remaining demand, if any, is confronted with firms' inventories always considering $s_{i, t}$ until its complete fulfillment or the total depletion of inventories. Goods depreciate completely in one period, thus every firm starts any period with no inventories. Firms' costs encompass labor costs, $w_{t} L_{i, t}$, and debt commitments, $i_{i, t} B_{i, t}^{S}$, where $i_{i, t}$ is the nominal interest rate charged on loans to an individual firm. 
The individual price $p_{i, t}$ is determined by applying an individual markup, $\mu_{i, t}$, on the nominal wage. ${ }^{5}$ The markup follows a behavioral rule, which is adapted from Dosi et al. (2013):

$$
\mu_{i, t}=\mu_{i, t-1} \cdot\left(1+\varphi \frac{s_{i, t-1}-s_{i, t-2}}{s_{i, t-2}}\right) \cdot\left(\frac{c_{t-1}}{c_{t-2}}\right)
$$

where $0<\varphi<1$ and $c_{t}$ is logarithm of the aggregate demand. The above expression can be interpreted in the following way: if the firm loses market share, it will try to recover it by reducing its markup (see equation 7 below); moreover, a fall in aggregate demand also means lower profits, and the firm will adopt the same strategy in order to increase its market share and hence keeps its revenues. An individual firm's market share evolves according to the following rule inspired in Dosi et al. (2013):

$$
s_{i, t}=s_{i, t-1} \cdot\left(1+\frac{\mu_{t}^{M}-\mu_{i, t-1}}{\mu_{t}^{M}}\right)
$$

where $\mu_{t}^{M}$ is the average markup at period t. Consequently, more competitive firms increase their market share.

Meanwhile, the dynamics of the individual net worth is given by $N W_{i, t}=N W_{i, t-1}+(1-\delta) \pi_{i, t}$. At any period, firms with a negative net worth are expelled from the model. For simplicity, the number of firms is kept constant. The sum of the market share of bankrupt firms is randomly distributed among entrant firms. The other attributes of entrant firms (leverage target, net worth and markup) are drawn from $N\left(M_{I}, 0.2 M_{I}\right)$, where $M_{I}$ is the average value of the corresponding attribute of incumbent firms, taking into account the minimum levels set at Table 3 below.

\subsection{The banking system}

The amount of credit supplied by the banking system at any period is limited by the capital requirement set by the central bank, represented by the parameter $\mathrm{k}$, where $0<k<1$, so that $B_{t}^{S} \leq N W_{t}^{B} / k$. Thus, the banking system is required by the central bank to keep a minimum net worth over the loans ratio equal to $k$. The maximum flow of credit at period $\mathrm{t}, B_{t}^{F}$, is given by the difference between the maximum credit supply allowed and the funds already lent:

$$
B_{t}^{F}=\max \left(N W_{t}^{B} / k-\sum_{t-t_{D}+1}^{t-1} B_{t}^{F}, 0\right)
$$

We suppose that the firms' capital structure is determined by the "dynamic trade-off theory" (Riccetti et al., 2013). The "trade-off theory" (Jensen and Meckling, 1976; Myers, 1977) is based on the trade-off between the costs and benefits of debt, implying that firms choose a leverage level, defined as the debt/net worth ratio. Riccetti et al. (2013) proposed a dynamic version of this theory, according to which the adjustment of leverage towards a long-run target is governed by market frictions. The credit demanded by firm $i$ at period $t$ is given by:

$$
B_{i, t}^{F}=\max \left(l_{i, t}^{*} \cdot N W_{i, t}-\sum_{t-t_{D}+1}^{t-1} B_{i, t}^{F}, 0\right)
$$

In the equation above, $l_{i, t}^{*}$ denotes the desired leverage. Therefore, if the stock of debt of the firm in the beginning of the period is below the maximum it is willing to borrow $\left(l_{i, t}^{*} \cdot N W_{i, t}\right)$, it will ask for more loans. The desired leverage level evolves according to the following behavioral rule:

$$
l_{i, t}^{*}=l_{i, t-1}^{*} \cdot\left(1+\lambda \cdot \frac{C_{i, t-1}-C_{i, t-2}}{C_{i, t-2}}\right)
$$

where $0<\lambda \leq 1$. The change in $l_{i, t}^{*}$ is constrained to $10 \%$ per period, which is intended to impose enough cautiousness on agents' willingness to adjust their desired leverage. A rise in the demand for their output

\footnotetext{
${ }^{5}$ The assumption of markup pricing behavior goes in hand with robust survey data evidence (e. g., Fabiani et al., 2006).
} 
will lead firms to revise upwards their desired leverage: they will ask for more loans in order to produce more and meet the higher sales. This rule can also be thought of as being driven by the very rationale of the banking system, as it is willing to lend to the more profitable firms.

Once $B_{t}^{F}$ is established, firms are sorted in descending order according to their net worth and their credit demands are fulfilled until the limit given by $B_{t}^{F}$ is achieved. The nominal interest rate charged on each individual firm, $i_{i, t}$, is established by applying a specific markup, $\mathrm{h}_{\mathrm{i}, \mathrm{t}}$, on the base interest rate, $i^{B}\left(1+h_{i, t}\right)$, where:

$$
h_{i, t}=0.5 \cdot\left(N W_{t}^{B}\right)^{-\gamma}+0.5 \cdot\left(l_{i, t}\right)^{\gamma}
$$

In the preceding expression, $i^{B}$ is the base interest rate set by the central bank and $\gamma$ is a positive risk premium parameter, $0<\gamma<1$. The first term implies that a sounder banking system will charge a lower interest rate. Besides, as implied by the second term, the interest rate paid by a firm is increasing in the firm's risk level, as measured by its leverage.

The nominal profit of the banking system is given by:

$$
\pi_{t}^{B}=\sum_{N W>0} i_{i, t} B_{i, t}^{S}-B D_{t}
$$

Therefore, the banking system receives the debt commitments of the firms with positive net worth and face a loss which is equal to the bad debt, whose definition as the absolute sum of the net worth of the bankrupt firms follows Delli Gatti et al. (2007): $B D_{t}=-\sum_{N W \leq 0} N W_{i, t}$. The banking system's net worth evolves according to $N W_{t}^{B}=N W_{t-1}^{B}+\pi_{t}^{B}$. If the banking system has a non-positive net worth, it is replaced by a new one with a net worth equal to $\sum N W_{i, t} \cdot{ }^{6}$

\section{Simulations: the passive policy case}

In this section, we run simulations considering that economic policy (monetary policy and prudential regulation) is merely passive. Therefore, the policy instruments $\mathrm{k}$ and $i^{B}$ are exogenous rather than endogenously updated according to some adaptive rule. The parameters and initial conditions are reported in Table 3 . $^{7}$

\subsection{Baseline simulations}

Figures 1 and 2 displays some basic statistics generated by the model, where we considered the average of 100 simulations. It can be seen that, after a transient period, the system oscillates around a relatively stable long-run level. In the initial periods, the more competitive firms grab a bigger slice of aggregate demand and grow faster than the other firms, which can be seen by the increasing variability concerning net worth and markup (Figure 3). After a big bust around period 80, when a great number of less competitive firms is eliminated, firms became more uniform, as entrant firms are random copies of the incumbent ones. Without remarkable differences regarding firms' competitiveness, as measured by their markups, oscillations became less pronounced. Inequality regarding firms' net worth and real output, as measured by the Herfindahl-Hirschman Index, is very low, although it increases after the transient period.

There is no long-run growth, which is expected given the lack of any source of growth (e.g., increase in the number of firms or in labor productivity). Similarly to other agent-based models, the model herein is able to endogenously generate business cycles. When the economy is in the boom period, firms revise upward their leverage target, engendering higher levels of production and subsequent growth

\footnotetext{
${ }^{6}$ In all simulation runs, no banking system bankruptcy was observed.

${ }^{7}$ No validation exercise on empirical data was performed, but using reasonable parameter values was always a major concern. In fact, most of the parameter values were drawn from existing studies (e.g., Riccetti et al., 2013). We run simulations on a range of reasonable values and chose a set of parameters whose results were not counterintuitive on empirical grounds.
} 
in aggregate demand. Firms' higher profits also keep the banking system in good financial shape, thus ensuring the necessary supply of credit. Such solid banking system' equity position pushes the interest rate down, while prices are pushed up. The credit expansion, combined with decreasing returns to net worth, spawns a greater credit-to-output ratio. In the descending phase, firms cut down markups to try to keep their market shares and avoid higher losses. The consequent shrink in the leverage level reinforces the reduction of output and aggregate demand. Eventually, some firms go bankrupt, which reduces the banking system's net worth. This can cause credit rationing, which creates a new source of instability.

Note that the system is adaptive, in the sense that ill-suited firms are expelled from the model and new firms are random copies of the surviving ones. Therefore, the financial fragility of the system decreases over time. The bad debt over total credit stabilizes around 1.5\%. The number of firms eliminated in each period also goes down until around $2 \%$ of the total number of firms. In general, bankrupt firms are young, with an average age not higher than 10 periods, while this value is below 5 in the long-run. Inventories reach $8 \%$ of total output. All these dynamics are shown in Figure 4.

\subsection{Interest rate shock}

We then run simulations including an interest rate shock, in the form of a temporary increase in $i^{B}$. The base interest rate is the instrument used by the central bank to implement its monetary policy. Thus, it is worth exploring how changes in this variable affect the real economy, as well as the price level and the financial fragility, which is measured here as the bad debt-to-aggregate credit ratio.

We considered that, at period 1,000, the base interest rate varies positively by $\Delta r$ and, after 50 periods, it turns back to its previous level. Note that the model replicates two kinds of tradeoffs: the inflation/output tradeoff and the inflation/financial stability tradeoff (Figure 5). Increases in the base interest rate reduce profits, thus affecting negatively consumption (through dividends) and output (through retained profits). Cascade effects take place, provoking further decreases in aggregate demand and production. In order to minimize profit losses, firms reduce markups to try to gain market share, which pushes prices down. Lower profits increase the occurrence of bankruptcies, thus worsening financial stability. An opposite mechanism takes place in case of a negative interest rate shock.

For large absolute values of $\Delta r$ (above $25 \%$ of base interest rate), the macroeconomic effects of negative and positive shocks became asymmetric, being much stronger in the former case. In fact, they preclude the system from returning to its original path. This phenomenon does not seem to have much robust empirical support, but it can be logically and intuitively explained by characteristics of the model. After the transient period, eliminated firms have an average level of leverage which is smaller than that of the incumbent ones (Figure 2). With a positive interest rate shock, the resulting fall in aggregate demand forces leverage down. However, financial fragility increases, which attenuates such decrease in the leverage level and, consequently, in the output production: there will be more low-leveraged firms being eliminated and more high-leveraged firms being created, as entrant firms are random copies of incumbent ones. Meanwhile, a similar mechanism which can attenuate the change in leverage does not exist in the case of a negative interest rate shock.

\section{Implementing monetary policy and prudential regulation}

In this section, we explore how the system is affected by an active economic policy. We assume that the central bank has two targets: macroeconomic stability (hereafter, MS) and financial stability (FS). To reach each one of these objectives, it relies on two instruments, respectively, the base interest rate $i^{B}$ and the capital requirement ratio $\mathrm{k}$.

The base interest rate is set according to a Taylor-type rule:

$$
i_{t}^{B}=\chi \cdot i_{t-1}^{B}+(1-\chi) \cdot\left[r^{*}+\pi_{t-1}+\theta_{1} \pi_{t-1}+\theta_{2}\left(y_{t-1}-y^{T}\right)+\theta_{3}\left(b_{t-1}-b^{T}\right)\right]
$$

In the equation above, $r^{*}$ is the equilibrium real interest rate, $\pi$ is the observed inflation, $y$ is the natural $\log$ of $\mathrm{Y}, y^{T}$ is the natural $\log$ of the potential output, $b$ is the nominal credit-to-nominal output ratio, $b^{T}$ is the potential level of $\mathrm{b}, \chi$ is a smoothing parameter between 0 and 1 and $\theta_{1}, \theta_{2}$ and $\theta_{3}$ are 
positive parameters. Both $y^{T}$ and $b^{T}$ are estimated applying the Hodrick-Prescott filter on the last $t_{H P}$ observations. $^{8}$ It is implicitly assumed that the inflation target is zero. The base interest rate is never set below $0.1 \%$. rules:

By setting different values to parameters in equation (13), we explore the effects of three types of

i. Traditional Taylor rule (TTR): $\chi=\theta_{3}=0, \theta_{1}=\theta_{2}=0.5$. This establishes the rule proposed by Taylor (1993) in his seminal paper.

ii. Interest-rate smoothing (IRS): $\theta_{3}=0, \theta_{1}=\theta_{2}=0.5,0<\chi<1$. In the actual conduct of monetary policy, central banks are frequently prone to adopt an inertial monetary policy, adjusting partially the policy interest rate. Clarida et al. (2000) estimate the smoothing parameter as ranging from 0.7 to 0.9. Some researchers claim that this can be an optimal behavior on the part of the central bank. Sack and Wieland (2000), for instance, consider that interest rate smoothing may be optimal due to three features of the environment in which monetary policy is conducted: forward-looking behavior by market participants, measurement error of key macroeconomic variables and uncertainty regarding structural parameters.

iii. "Leaning against the wind" interest rate (LAW): $\chi=0, \theta_{1}=\theta_{2}=0.5, \theta_{3}>0$. There is an intense discussion about whether monetary policy should react when an asset price bubble is identified or just after the bubble burst - the "lean versus clean" debate. The recent financial crisis has provided some arguments in favor of the first option (Canuto and Cavallari, 2013). We explore this rule by using a variable associated with the booming of asset bubbles, viz. the credit expansion. Then we incorporate to the TTR a component which is sensible to the credit-to-output gap.

Regarding the capital requirement, we consider that it now incorporates a cyclical component $k_{t}^{C}$ :

$$
k_{t}=k^{*}+k_{t}^{C}
$$

As originally proposed by the Basel III accord (BCBS, 2010), we establish $k^{*}=0.08$, while $k_{t}^{C}$ varies according to the credit-to-output gap:

$$
k_{t}^{C}=\left\{\begin{array}{ccc}
0 & \text { if } & g_{t-1} \leq L \\
0.025 \cdot \frac{g_{t-1}-L}{H-L} & \text { if } & L<g_{t-1}<H \\
0.025 & \text { if } & g_{t-1} \geq H
\end{array}\right.
$$

where $g_{t}=b_{t}-b^{T}$ is the credit-to-output gap and L (H) is the lower (higher) threshold. In BCBS (2010), the suggested values for $\mathrm{L}$ and $\mathrm{H}$, which we adopt here, are 0.02 and 0.10 , respectively.

In the following analysis, this first rule is called the Basel III rule (BAS). Alternatively, we test a second capital requirement rule, which is adopted, for instance, in Agénor et al. (2013). Here, the capital requirement is $k_{t}=k^{*}+\theta^{C} g_{t-1}$, with $\theta^{C}>0$. In the following analysis, we refer to this rule as the unbounded capital requirement rule (UNB).

Departing from UNB, we explore two more rules. Firstly, we analyze the effect of the capital requirement smoothing (CRS) rule, by setting $k_{t}=\chi \cdot k_{t-1}+(1-\chi) \cdot\left(k^{*}+\theta^{C} g_{t}\right)$. The latter is underpinned by the same rationale of IRS. Capital requirement smoothing is a way to tackle the problem of procyclicality of capital requirement rules under the Internal Ratings Based (IRB) approach, which includes Basel II accord (Hordy and Howells, 2006). Finally, the use of the deviation of the credit-tooutput ratio from its trend in setting of capital requirement is criticized by many authors. Repullo et al.

\footnotetext{
${ }^{8}$ Whenever the Hodrick-Prescott filter was applied in this paper, we set $t_{\mathrm{HP}}=20$.
} 
(2010) point out that it would exacerbate the pro-cyclicality of risk-sensitive bank capital regulation, as for many countries the credit-to-GDP gap is negatively correlated with GDP growth. Some studies suggest that the credit growth rate is a better reference point. Therefore, we implement the credit growth capital requirement rule (CGR), according to which the capital requirement ratio is established according to $k_{t}=k^{*}+\theta^{C}\left(\ln B_{t-1}-\ln B^{T}\right)$, where $\mathrm{B}^{\mathrm{T}}$ is the potential credit, which is also estimated through the Hodrick-Prescott filter.

As stated earlier, the central bank is concerned with macroeconomic stability and financial stability. We assume that the former depends negatively on the volatility of output and prices, as measured by their coefficients of variation, while the latter is measured by the ratio bad debt-to-total credit. We explore how the behavior of these three variables (coefficient of variation of real output, coefficient of variation of prices and average bad debt-to-credit) is affected by each combination of monetary policy rule and capital requirement rule.

\subsection{Results}

Tables 4-5 show the results of simulations. For each combination, it was run 100 simulations of 1,000 periods each. The values shown in the cells correspond to the difference between the average of the respective combination and that of the baseline case (fixed capital requirement and interest rate). We considered two cases: the mean across all the 1,000 periods (Table 4) and a similar series which excludes a transient phase comprising the first 200 periods (Table 5). We set $r^{*}=0.02, \chi=0.5$ and $\theta^{C}=0.5(0.1$ for CGR). For the "leaning against the wind" rule, three values of $\theta_{3}$ were tested: $0.1,0.5$ and 1 .

Our results show that the available instruments are individually effective. In fact, all the cyclical capital and interest rate rules, when applied alone, reduce their target variables (bad debt-to-credit in the first case, coefficient of variation of output and price in the second one). However, in some cases this efficiency has a temporal dimension. The "leaning against the wind" interest rate rule (LAW), when implemented alone, does not exhibit a long-run effect (ignoring the transient period); it just alleviates the output and price variation during the transient phase. Only few combinations present a long-run effect regarding price volatility. It is worth noting that some cyclical capital rules (notably UNB and CRS) have short-run positive effects on macroeconomic stability.

Some relevant policy implications can be inferred from the results. The cyclical capital component as suggested in the Basel III accord (BAS), notwithstanding being efficient when applied alone, loses its effectiveness when combined with an interest rate rule. A possible explanation is that changes in the interest rate require, in order to avoid a worsening of financial stability, a change in the capital requirement greater than that allowed in the BAS case, where the buffer is limited to $2.5 \%$. Moreover, it can be seen that the unbounded capital requirement rules (UNB, CRS and CGR) perform very well in articulation with interest rate rules, which provides further support to the possible explanation suggested above.

The "leaning against the wind" rule proved very damaging to financial stability in the short-term, but may promote it in the long-run when the interest rate is not too sensitive to credit changes $\left(\theta_{3}=0.1\right)$ and when it is combined with unbounded cyclical capital rules. Regarding the cyclical capital rules, the unbounded options (UNB, CGR and CRS) do not present any noticeable difference among themselves.

The best results for financial stability involve the smoothing of interest rate changes (IRS). This option proved slightly worse than other Taylor-type rules regarding macroeconomic stability, but this difference is not significant. Woodford $(1999,2001)$ discusses the optimality of interest rate smoothing. In fact, it reduces the likelihood of reaching the zero nominal interest rate floor in a low interest rate environment and decreases the average size of distortions caused by high interest rates (Woodford, 1999). Furthermore, if agents are forward-looking in such a way that current aggregate demand is affected by future interest rates, monetary policy inertia is optimal (Woodford, 2001).

This result goes in hand with the standpoint of some studies according to which interest rate smoothing enhances financial stability. It is claimed that, as banks convert variable rate liabilities in fixed rate assets, inertia in interest rates is favorable to their solvency (Padoa-Scioppa, 2002). Furthermore, our 
results corroborate the evidence found in Smith and van Egteren (2005), according to which IRS performs better with unbounded capital requirement rules. These authors point out that, if interest rate smoothing is in place, a higher capital requirement should be imposed, in order to avoid moral hazard problems stemming from the fact that banks are prone to be more risk-taking in a stable environment.

\subsection{Extending the analysis: varying $\theta^{C}$ and $\chi$}

From the analysis above, it follows that two parameters are crucial. First, the preceding results suggest that the sensitiveness of the cyclical capital requirement to credit variations $\left(\theta^{\mathrm{C}}\right)$ should be strong enough to countervail changes in interest rate in order to avoid a worsening in financial stability. Second, the interest rate smoothing $(0<\chi<1)$ overcomes both the fixed interest rate $(\chi=1)$ and the traditional Taylor rule $(\chi=0)$ cases. Therefore, it is worth exploring a wider range of values of these parameters.

We then changed $\theta^{\mathrm{C}}$ between 0 and 1 in increments of 0.1 . We used the UNB rule combined with three interest rate rules: TTR, IRS and LAW. For each value of the parameter 100 simulations were run and the average of the variables of interest (mean bad debt, coefficient of variation of real output and coefficient of variation of price) was calculated. The same procedure was adopted regarding $\chi$ with a ceiling of 0.9. In this case, an interest rate rule (IRS) was combined with three cyclical capital component rules (UNB, CRS and CGR). In both situations, we analyze the no-transience-phase case and the one in which the transience phase comprises the first 200 periods.

Figure 6 shows that, when a transient period is considered, there appears to be a nonlinear Ushaped relationship between the variables and $\theta^{\mathrm{C}}$. The fit in the convex curve is poor when the interest rate smoothing is applied, considering the financial stability, which is shown by the low adjusted $\mathrm{R}^{2}$ (Table 6). Such result is expected, as in this case the financial stability stems essentially from the smoothed interest rate and relies less on $\theta^{\mathrm{C}}$. However, in the transient phase case, while average bad debt keeps its convex relationship with $\theta^{\mathrm{C}}$, the variables related to macroeconomic stability become concave functions of the parameter. This can be explained in light of the adaptive process which takes place during the transient phase. For values of $\theta^{\mathrm{C}}$ below the turning point level (around 0.7), the elimination of less adapted firms - that is, those with lower net worth - due to a tightening of the credit supply is more severe. As entrant firms are random copies of incumbent ones, this increases firms' average net worth. As a result, the peak of the aggregate output and price level is more pronounced.

Regarding the smoothing parameter (Figure 7), a similar result is observed. In the long-run, an increase in $\chi$ contributes to greater financial stability and its effects on macroeconomic stability are positive or negligible depending on the case. But in the short term output and price volatility is a convex function of the parameter. Again this can be understood by looking at the dynamics of the system in its early stages. When smoothed, the interest rate does not rise by as much as it would be necessary to dampen output and prices in the ascendant phase of the cycle.

\section{Concluding remarks}

In this paper, we set forth an $\mathrm{AB}$ model well suited to performing macroeconomic policy analysis. The main purpose is to derive qualitative results regarding the appropriate coordination between monetary policy and prudential regulation within this framework.

The model succeeds in replicating several important macroeconomic stylized facts (e.g., business cycles), as well as two tradeoffs which relevant to the issues addressed here: the inflation/output tradeoff and the inflation/financial stability tradeoff. A positive interest rate shock pushes both output and prices down. Furthermore, the resulting decrease in firms' profits increases the likelihood of bankruptcies, thus threatening financial stability.

We also explore how different combinations of monetary policy and prudential regulation rules affect macroeconomic and financial stability. Some relevant policy implications are drawn from this analysis. First, the implementation of a cyclical capital component as proposed in Basel III, while successful in reducing financial instability when applied alone, loses its efficacy when combined with the interest rate rules considered here. The reason might be that, in face of an interest rate change, it becomes 
necessary an accompanying change in the capital requirement which is higher than that allowed by the Basel III cyclical buffer rule.

Second, interest rate smoothing is more effective than the other interest rate rules assessed, as it outperforms them concerning financial stability and performs as well as them regarding macroeconomic stability. Moreover, interest rate smoothing achieves better results when combined with unbounded capital requirement rules. A possible explanation comes from Smith and van Egteren (2005): banks are more prone to adopt a risky behavior in a stable environment, so that a higher capital requirement should be implemented when the smoothing interest rate is in place.

Finally, there is no long-run tradeoff regarding the sensitiveness of the cyclical capital component to the credit-to-output ratio, as well as the smoothing interest rate parameter. In the long-run, there is a nonlinear U-shaped relationship between the variables measuring financial and macroeconomic stability (bad debt-to-credit ratio and output and price volatility) and the cyclical capital component to credit-tooutput ratio. Furthermore, financial stability is well fitted by a concave function of the smoothing interest rate parameter, whereas the same parameter has a positive or negligible effect on macroeconomic stability. Short-run tradeoffs appear due to the adaptive nature of the model.

Needless to say, all these qualitative results should be taken with caution. Agent-based models suffer from over-parametrization and their results are very sensitive to parameters and initial conditions. However, similar caution applies to other types of models addressing the same issues. Furthermore, the model set forth here is underpinned by an aggregate consistency between stocks and flows, a coherence of assumptions and the replication of stylized facts. Therefore, we believe that agent-based models along the lines of the one developed in this paper can be an important tool in the assessment of economic policies, acting complementarily to existing ones.

\section{References}

Agénor, P-R., Alper, K. and Silva, L. A. P. da (2013). "Capital Regulation, Monetary Policy, and Financial Stability". International Journal of Central Banking, 9 (3): 193-238.

Barnea, E., Landskroner, Y. and Sokoler, M. (2015). "Monetary policy and financial stability in a banking economy: Transmission mechanism and policy tradeoffs". Journal of Financial Stability, 18 (In Progress): 78-90.

Basel Committee on Banking Supervision (BCBS) (2010). "Guidance for national authorities operating the countercyclical capital buffer". Bank of International Settlements, Basel, Switzerland, December 2010.

(2012). "Models and tools for macroprudential analysis". BIS Working Paper No. 21,

May.

Beau, D., Clerc, L. and Mojon, B. (2011). "Macro-prudential Policy and the Conduct of Monetary Policy". Bank of France Occasional Paper No. 8.

Bernanke, B. S. and Gertler, M. (1995). "Inside the black box: the credit channel of monetary policy transmission". Journal of Economic Perspectives, 9 (4): 27-48.

Bookstaber, R. (2012). "Using Agent-Based Models for Analyzing Threats to Financial Stability". Office of Financial Research Working Paper No. 0003.

Canuto, O. and Cavallari, M. (2013). "Monetary Policy and Macro Prudential Regulation: Whither Emerging Markets". In Canuto, O. e Gosh, S. R. (eds.), Dealing with the Challenges of Macro Financial Linkages in Emerging Markets. The World Bank: Washington, D. C.

Cincotti, S., Raberto, M. and Teglio, A. (2011). "The EURACE macroeconomic model and simulator". 16th IEA World Congress 2011.

Cincotti, S., Raberto, M. and Teglio, A. (2012). "Macroprudential Policies in an Agent-Based Artificial Economy". Revue de l'OFCE, 124 (5): 205-234.

Clarida, R., Gali, J. and Gertler, M. (2000). "Monetary Policy Rules and Macroeconomic Stability: Evidence and Some Theory”. Quarterly Journal of Economics, 115: 147-180. 
Delli Gatti, D. and Desiderio, S. (2014). "Monetary policy experiments in an agent-based model with financial frictions". Journal of Economic Interaction and Coordination.

Delli Gatti, D., Di Guilmi, C., Gallegati, M. and Giulioni, G. (2007). "Financial Fragility, Industrial Dynamics and Business Fluctuations in an Agent Based Model". Macroeconomic Dynamics, 11 (S1): $62-$ 79.

Delli Gatti, D., Gallegati, M., Greenwald, B., Russo, A. and Stiglitz, J.E. (2010). "The financial accelerator in an evolving credit network". Journal of Economic Dynamics and Control, 34(9): 16271650.

Dosi, G., Fagiolo, G., Napoletano, M. and Roventini, A. (2013). "Income Distribution, Credit and Fiscal Policies in an Agent-Based Keynesian Model". Journal of Economic Dynamics and Control, 37 (8): 1598-1625.

Fabiani, S., Druant, M., Hernando, I., Kwapil, C., Landau, B., Loupias, C., Martins, F., Mathä, T., Sabbatini, R., Stahl, H. and Stokman, A. (2006). "What Firms' Surveys Tell Us about Price-Setting Behavior in the Euro Area". International Journal of Central Banking, 2 (3): 3-47.

Fagiolo, G. e Roventini, A. (2012). "Macroeconomic Policy in DSGE and Agent-Based Models". Revue de l'OFCE, 124 (5): 67-116.

Gallegati, M. e Kirman, A. (2012). "Reconstructing Economics: Agent Based Models and Complexity". Complexity Economics, 1: 5-31.

Goodhart, C. A. E., Kashyap, A. K., Tsomocos, D. P. and Vardoulakis, A. P. (2013). “An Integrated Framework for Analyzing Multiple Financial Regulations". International Journal of Central Banking, 9 (S1): 109-143.

Gordy, M. B. and Howells, B. (2006). "Procyclicality in Basel II: Can we Treat the Disease without Killing the Patient?". Journal of Financial Intermediation, 15: 396-418.

International Monetary Fund (IMF). (2013). "The interaction of monetary and macroprudential policies". January.

Jensen, M.C. and Meckling, W.H. (1976). "Theory of the Firm: Managerial Behavior, Agency Costs, and Ownership Structure". Journal of Financial Economics, 3: 305-360.

Krug, S., Lengnick, M. and Wohltmann, H. W. (2014). "The impact of Basel III on financial (in) stability: An agent-based credit network approach". Economics Working Paper No. 2014-13, Christian-AlbrechtsUniversität Kiel, Department of Economics.

Krugman, P. (1996). The Self-Organizing Economy. Oxford: Blackwell (Basil).

(2011). "The Profession and the Crisis". Eastern Economic Journal, 37: 307-312.

Lambertini, L., Mendicino, C. and Punzi, M. T. (2013). "Leaning against boom-bust cycles in credit and housing prices". Journal of Economic Dynamics and Control, 37 (8): 1500-1522.

Mandel, A., Jaeger, C., Fuerst, S., Lass, W., Lincke, D., Meissner, F., Pablo-Marti, F. and Wolf, S. (2010). “Agent-Based Dynamics in Disaggregated Growth Models". Working Paper 2010.77, CES.

Myers, S.C. (1977). "Determinants of corporate borrowing". Journal of Financial Economics, 5(2): 147175.

Padoa-Schioppa, T. (2002). "Central banks and financial stability: exploring a land in between". Second ECB Central Banking Conference "The transformation of the European financial system", Frankfurt am Main, October 2002.

Raberto, M., Teglio, A. and Cincotti, S. (2008). "Integrating Real and Financial Markets in an AgentBased Economic Model: An Application to Monetary Policy Design". Computational Economics, 32: 147-162.

Repullo, R., Saurina, J. and Trucharte, C. (2010): "Mitigating the Pro-cyclicality of Basel II". Economic Policy, 64: 659-702.

Riccetti, L., Russo, A. and Gallegati, M. (2013). "Leveraged network-based financial accelerator". Journal of Economic Dynamics and Control, 37 (8): 1626-40.

Rotemberg, J. (2008). "Behavioral Aspects of Price Setting, and Their Policy Implications". NBER Working Paper 13754. 
Sack, B. and Wieland, V. (2000). "Interest-rate smoothing and optimal monetary policy: a review of recent empirical evidence". Journal of Economic and Business, 52: 205-228.

Smith, R. T. and van Egteren, H. (2005). "Interest rate smoothing and financial stability". Review of Financial Economics, 14 (2): 147-171.

Stiglitz, J. (2011). "Rethinking Macroeconomics: What Failed, and How to Repair It". Journal of the European Economic Association, 9: 591-645.

Taylor, J. B. (1993). "Discretion versus policy rules in practice". Carnegie-Rochester Conference Series on Public Policy, 39: 195-214.

Teglio, A., Raberto, M. and Cincotti, S. (2012). "The impact of banks' capital adequacy regulation on the economic system: an agent-based approach". Advances in Complex Systems, 15 (S2).

Woodford, M. (1999). "Optimal monetary policy inertia". CFS Working Paper, No. 1999/09.

(2): 232-237. (2001). "The Taylor Rule and Optimal Monetary Policy". American Economic Review, 91

\section{Appendix: Tables and Figures}

Table 1: Balance sheets

\begin{tabular}{lcc}
\hline Agents & Assets & Liabilities \\
\hline \hline \multirow{2}{*}{ Firms } & $\mathrm{K}$ & $\mathrm{B}$ \\
\hline \multirow{2}{*}{ Banking system } & $\mathrm{R}$ & $\mathrm{NW}$ \\
\cline { 2 - 3 } & $\mathrm{B}$ & $\mathrm{D}$ \\
\hline Firm-owners & $\mathrm{D}^{\mathrm{K}}$ & $\mathrm{NW}^{\mathrm{B}}$ \\
\hline
\end{tabular}

Table 2: Flow of funds

\begin{tabular}{lcccc}
\hline & Firms & Banking system & Workers & Firm-owners \\
\hline \hline Production & $p Y$ & & $-w L$ & $-A^{*}$ \\
Wages & $-w L$ & $w L$ & \\
Dividends & $-A^{*}$ & & & $A^{*}$ \\
Debt commitments & $-i B$ & $i B$ & & \\
\hline
\end{tabular}

$(*)$ : As will be detailed later, dividends are paid at period $\mathrm{t}$ and consumed at period $\mathrm{t}+1$. Thus, dividends in the first row have a different value from those in the third one.

Table 3: Parameters and initial conditions

\begin{tabular}{|c|c|c|}
\hline Symbol & Meaning & Value \\
\hline \multicolumn{3}{|c|}{ Parameters } \\
\hline $\mathrm{N}$ & Number of firms & 500 \\
\hline$\alpha$ & Production parameter (see equation 1 ) & 3 \\
\hline$\beta$ & Production parameter (see equation 1 ) & 0.7 \\
\hline$t_{D}$ & Duration of debts (in periods) & 10 \\
\hline$\psi$ & Real wage lower limit parameter (see equation 3) & 0.95 \\
\hline$\delta$ & Fraction of profits distributed as dividends & 0.5 \\
\hline$\varphi$ & Markup sensitivity to a change in market share (equation 6) & 0.2 \\
\hline$\lambda$ & Leverage sensitivity to a change in demand (equation 10) & 1 \\
\hline$i^{B}$ & Base interest rate & 0.02 \\
\hline $\mathrm{k}$ & Capital requirement ratio & 0.08 \\
\hline$\gamma$ & Risk premium parameter (see equation 11) & 0.02 \\
\hline \multicolumn{3}{|c|}{ Initial conditions } \\
\hline$N W_{i, 0}{ }^{(1)}$ & Firms' initial net worth & $N W_{i, 0} \sim N(10,2)$ \\
\hline$\mu_{i, 0}^{(2)}$ & Firms' initial markup & $\mu_{i, 0} \sim N\left(\begin{array}{ll}0.15, & 0.03)\end{array}\right)$ \\
\hline$w_{0}$ & Initial nominal wage & \\
\hline
\end{tabular}


$l_{i, 0}^{*}$

Firms' initial leverage target

$S_{i, 0}$

Firms' initial market share

$N W_{o}^{B} \quad$ Banking system's initial net worth
(1): Initial net worth is never set below 1.

$l_{i, 0}^{*} \sim U(0.01,3)$

$N W_{i, 0} / \sum N W_{i, 0}$

$k \sum N W_{i, 0}$

(2): Initial markup is never set below $1 \%$.

Table 4: Results of simulations, no transient phase

\begin{tabular}{|c|c|c|c|c|c|c|}
\hline \multirow{2}{*}{$\mathrm{k} \backslash \mathrm{i}^{\mathrm{B}}$ Rule } & \multirow{2}{*}{ FIR } & \multirow{2}{*}{ TTR } & \multirow{2}{*}{ IRS } & \multicolumn{3}{|c|}{ LAW } \\
\hline & & & & $\theta_{3}=0.1$ & $\theta_{3}=0.5$ & $\theta_{3}=1.0$ \\
\hline \multicolumn{7}{|c|}{ Coefficient of variation of the real output } \\
\hline FCR & - & $-0.9961 * * *$ & $-0.9342 * * *$ & $-0.9888 * * *$ & $-1.0287 * * *$ & $-0.9888 * * *$ \\
\hline BAS & -0.0300 & $-0.9819 * * *$ & $-0.8998 * * *$ & $-0.9947 * * *$ & $-1.0607 * * *$ & $-1.0582 * * *$ \\
\hline UNB & $-0.1144 * *$ & $-0.8941 * * *$ & $-0.8084 * * *$ & $-0.8915 * * *$ & $-0.9908 * * *$ & $-1.0264 * * *$ \\
\hline CRS & $-0.1378 * * *$ & $-0.9063 * * *$ & $-0.8601 * * *$ & $-0.9247 * * *$ & $-1.0431 * * *$ & $-1.0634 * * *$ \\
\hline CGR & 0.0171 & $-0.9135 * * *$ & $-0.8589 * * *$ & $-0.9327 * * *$ & $-1.0251 * * *$ & $-1.0724 * * *$ \\
\hline \multicolumn{7}{|c|}{ Coefficient of variation of prices } \\
\hline FCR & - & $-0.0129 * * *$ & $-0.0117 * * *$ & $-0.0126 * * *$ & $-0.0129 * * *$ & $-0.0126 * * *$ \\
\hline BAS & $-0.0025 * *$ & $-0.0128 * * *$ & $-0.0113 * * *$ & $-0.0125 * * *$ & $-0.0131 * * *$ & $-0.0130 * * *$ \\
\hline UNB & $-0.0036 * * *$ & $-0.0120 * * *$ & $-0.0109 * * *$ & $-0.0120 * * *$ & $-0.0124 * * *$ & $-0.0125 * * *$ \\
\hline CRS & $-0.0044 * * *$ & $-0.0120 * * *$ & $-0.0113 * * *$ & $-0.0122 * * *$ & $-0.0130 * * *$ & $-0.0126 * * *$ \\
\hline CGR & 0.0001 & $-0.0120 * * *$ & $-0.0111 * * *$ & $-0.0125 * * *$ & $-0.0129 * * *$ & $-0.0130 * * *$ \\
\hline \multicolumn{7}{|c|}{ Mean bad debt-to-credit } \\
\hline FCR & - & $0.1572 * * *$ & 0.0572 & $0.3461 * * *$ & $0.4917 * * *$ & $0.3461 * * *$ \\
\hline BAS & $-0.1128 * * *$ & $0.2182 * * *$ & 0.1059 & $0.2670 * * *$ & $0.4961 * * *$ & $0.5550 * * *$ \\
\hline UNB & $-0.1450 * * *$ & -0.0320 & $-0.1568 * * *$ & 0.0690 & $0.2323 * * *$ & $0.6327 * * *$ \\
\hline CRS & $-0.1715 * * *$ & 0.0568 & $-0.1104 * *$ & $0.1240 * *$ & $0.4134 * * *$ & $0.7056 * * *$ \\
\hline CGR & $-0.0780 *$ & 0.0204 & -0.0807 & 0.0438 & $0.3843 * * *$ & $0.7633 * * *$ \\
\hline
\end{tabular}

Values correspond to the difference between the mean of the combination and that of the baseline case (FCR $\mathrm{x}$ FIR). The significance level is set according to the F-test of equality of means. (*): Significant at $10 \%$. (**): Significant at $5 \%$. (***):

Significant at $1 \%$.

Table 5: Results of simulations, transient phase $=200$ first periods

\begin{tabular}{|c|c|c|c|c|c|c|}
\hline \multirow{2}{*}{$\mathrm{k} \backslash \mathrm{i}^{\mathrm{B}}$ Rule } & \multirow{2}{*}{ FIR } & \multirow{2}{*}{ TTR } & \multirow{2}{*}{ IRS } & \multicolumn{3}{|c|}{ LAW } \\
\hline & & & & $\theta_{3}=0.1$ & $\theta_{3}=0.5$ & $\theta_{3}=1.0$ \\
\hline \multicolumn{7}{|c|}{ Coefficient of variation of the real output } \\
\hline FCR & - & $-0.0788^{*}$ & $-0.0753 *$ & -0.0584 & -0.0462 & -0.0584 \\
\hline BAS & -0.0481 & -0.0637 & -0.0506 & -0.0354 & -0.0648 & -0.0630 \\
\hline UNB & 0.0130 & $-0.1119 * * *$ & $-0.0860 * *$ & $-0.1180 * * *$ & $-0.0922 * *$ & $-0.0720 *$ \\
\hline CRS & -0.0395 & $-0.0991 * *$ & -0.0677 & $-0.0959 * *$ & -0.0569 & -0.0458 \\
\hline CGR & 0.0750 & $-0.0986 * *$ & $-0.0745^{*}$ & $-0.0891 * *$ & $-0.0689 *$ & -0.0517 \\
\hline \multicolumn{7}{|c|}{ Coefficient of variation of prices } \\
\hline FCR & - & -0.0004 & -0.0005 & -0.0001 & 0.0001 & -0.0001 \\
\hline BAS & -0.0004 & -0.0001 & -0.0001 & 0.0004 & 0.0000 & 0.0001 \\
\hline UNB & 0.0007 & $-0.0009 * *$ & $-0.0007^{*}$ & $-0.0009 * *$ & -0.0005 & 0.0002 \\
\hline CRS & -0.0002 & $-0.0007 *$ & -0.0006 & -0.0007 & 0.0001 & 0.0006 \\
\hline CGR & 0.0009 & -0.0006 & -0.0005 & -0.0006 & -0.0000 & 0.0003 \\
\hline \multicolumn{7}{|c|}{ Mean bad debt-to-credit } \\
\hline FCR & - & -0.0428 & $-0.1639 * *$ & 0.1270 & $0.1912 * *$ & 0.1270 \\
\hline BAS & $-0.1021 * *$ & 0.0082 & -0.0892 & 0.0495 & $0.2323 * * *$ & $0.2133 * *$ \\
\hline UNB & $-0.1298 * * *$ & $-0.2798 * * *$ & $-0.3751 * * *$ & $-0.1727 * * *$ & -0.0259 & $0.4712 * * *$ \\
\hline CRS & $-0.1599 * * *$ & $-0.1707 * * *$ & $-0.3244 * * *$ & $-0.1029 * *$ & $0.2052 * * *$ & $0.5722 * * *$ \\
\hline CGR & $-0.0912 * *$ & $-0.2052 * * *$ & $-0.3118 * * *$ & $-0.1404 * *$ & $0.2102 * * *$ & $0.5746^{* * *}$ \\
\hline
\end{tabular}

Values correspond to the difference between the mean of the combination and that of the baseline case (FCR x FIR). The significance level is set according to the F-test of equality of means. (*): Significant at $10 \%$. (**): Significant at $5 \%$. $(* * *)$ : Significant at $1 \%$. 
Table 6: Adjusted $\mathrm{R}^{2}$ of regressions

\begin{tabular}{|c|c|c|c|c|c|c|}
\hline \multicolumn{7}{|l|}{$\theta^{\mathrm{C}}:$} \\
\hline \multirow{2}{*}{ Rule } & \multicolumn{2}{|c|}{ avg. bad debt-to-credit } & \multicolumn{2}{|c|}{ coeff. var. real output } & \multicolumn{2}{|c|}{ coeff. var. price level } \\
\hline & $(1)$ & $(2)$ & $(1)$ & $(2)$ & (1) & $(2)$ \\
\hline TTR & 0.8947 & 0.8165 & 0.7493 & 0.7398 & 0.8151 & 0.6211 \\
\hline IRS & 0.3595 & 0.6608 & 0.7646 & 0.6102 & 0.5426 & 0.2395 \\
\hline LAW & 0.8844 & 0.8783 & 0.7771 & 0.8917 & 0.8696 & 0.7891 \\
\hline \multicolumn{7}{|l|}{$\chi:$} \\
\hline UNB & 0.9307 & 0.9711 & 0.3425 & 0.3738 & 0.3857 & 0.9089 \\
\hline CRS & 0.9215 & 0.9514 & -0.0453 & 0.4919 & 0.2486 & 0.9831 \\
\hline CGR & 0.9695 & 0.9667 & 0.6980 & 0.6188 & 0.8547 & 0.9491 \\
\hline
\end{tabular}

(1): Transient phase. (2): No transient phase.
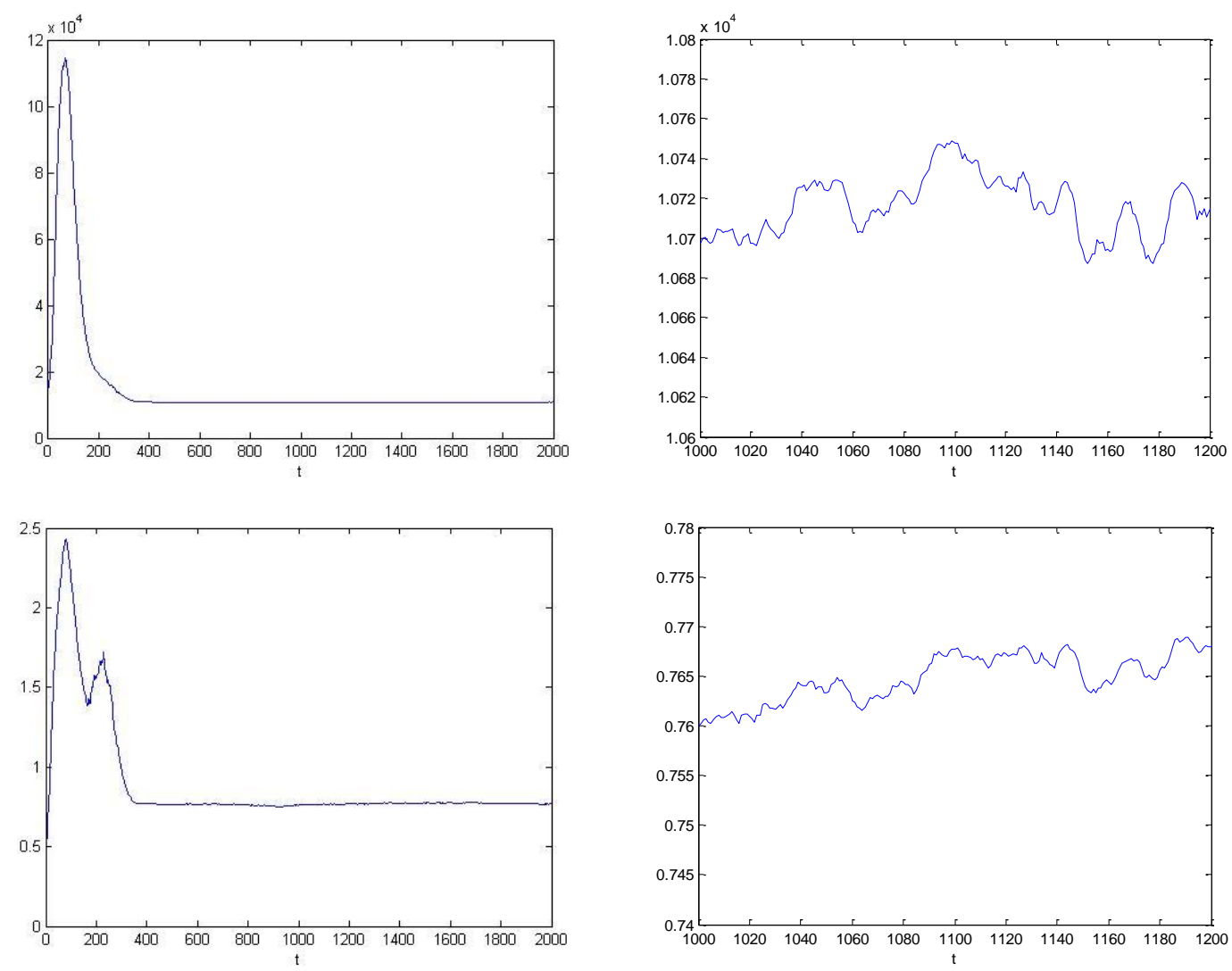

Figure 1: Left-hand side, from top-down: Real output and nominal credit-to-nominal output ratio. Right-hand side: the same variables in detail, considering a narrower time window. 

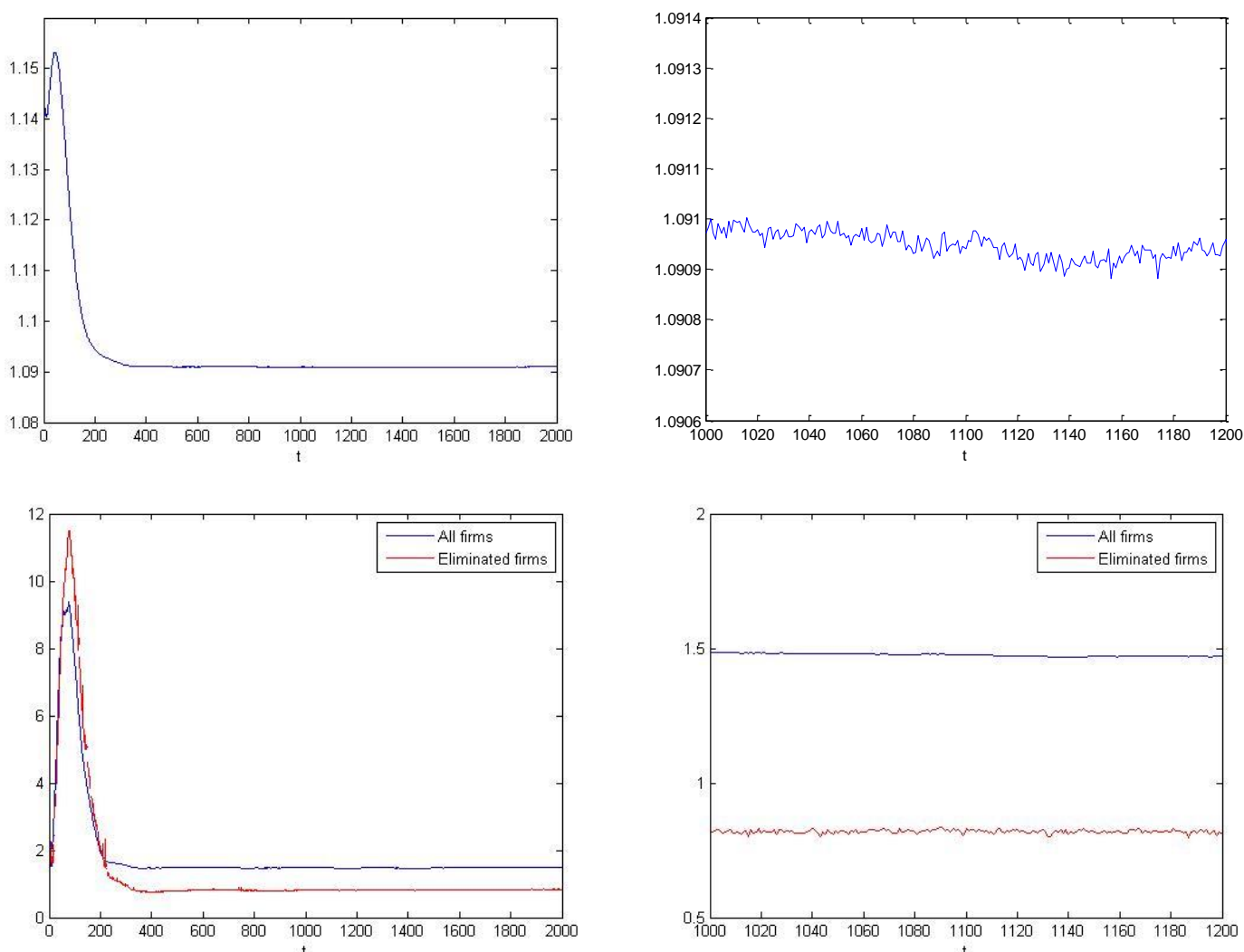

Figure 2: Left-hand side, from top-down: Price level and leverage. Right-hand side: the same variables in detail, considering a narrower time window.
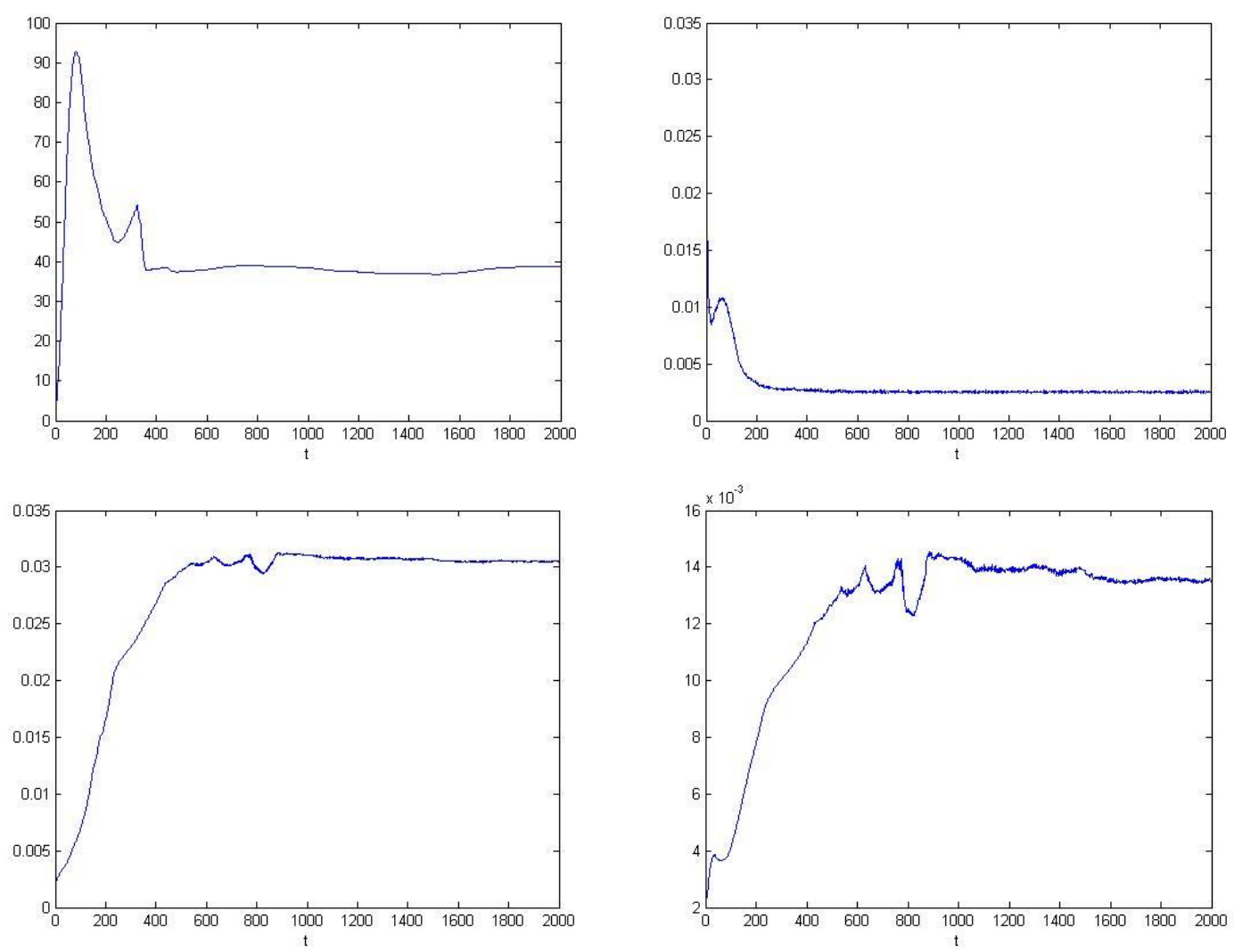

Figure 3: Above: Standard-deviation of firms' net worth (left) and markup (right). Below: Herfindahl-Hirschman Index of firms' net worth (left) and real output (right). 

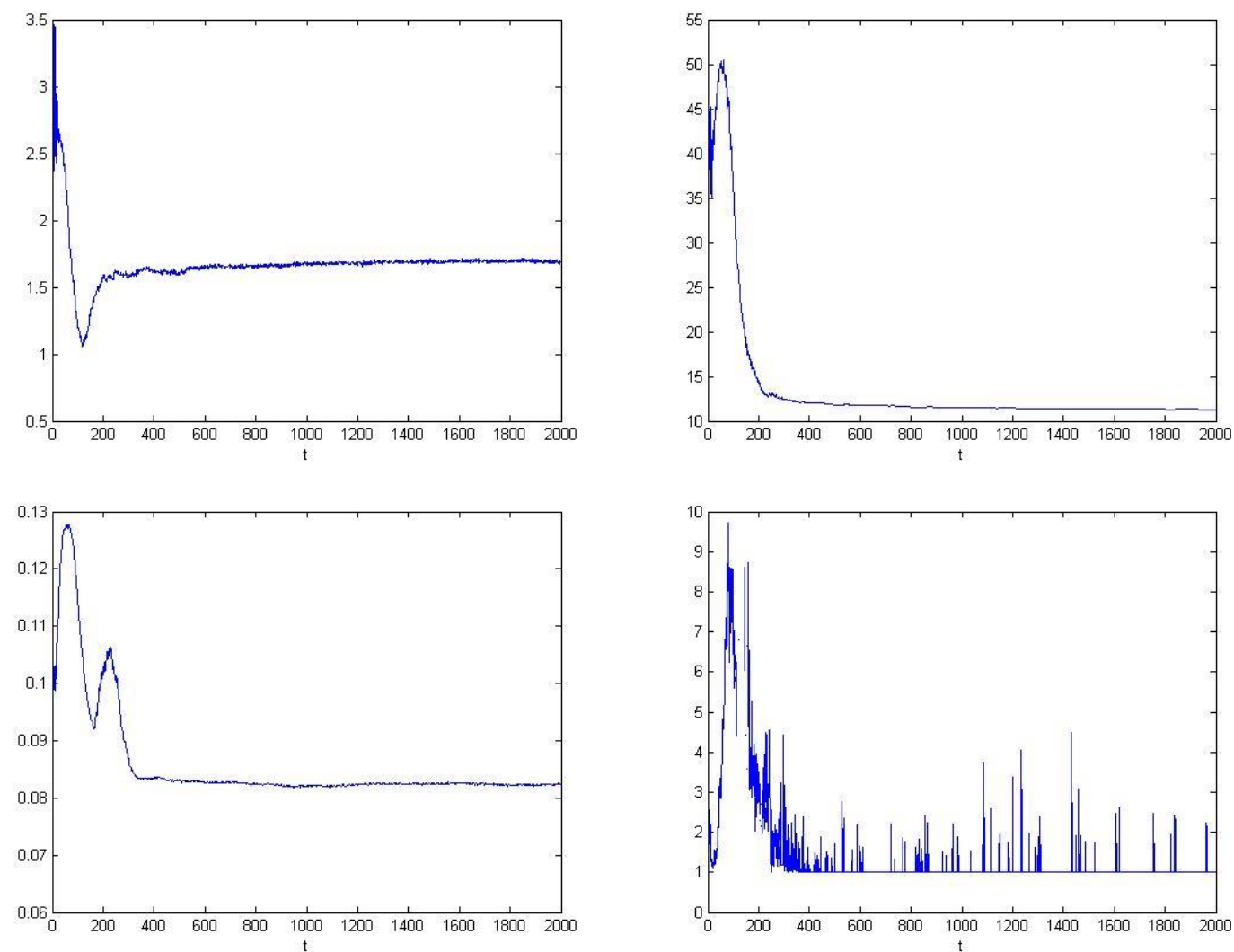

Figure 4: Bad debt as a percentage of total credit (top-left), number of eliminated firms per period (top-right), inventories over output (down-left) and average age of eliminated firms (down-right).
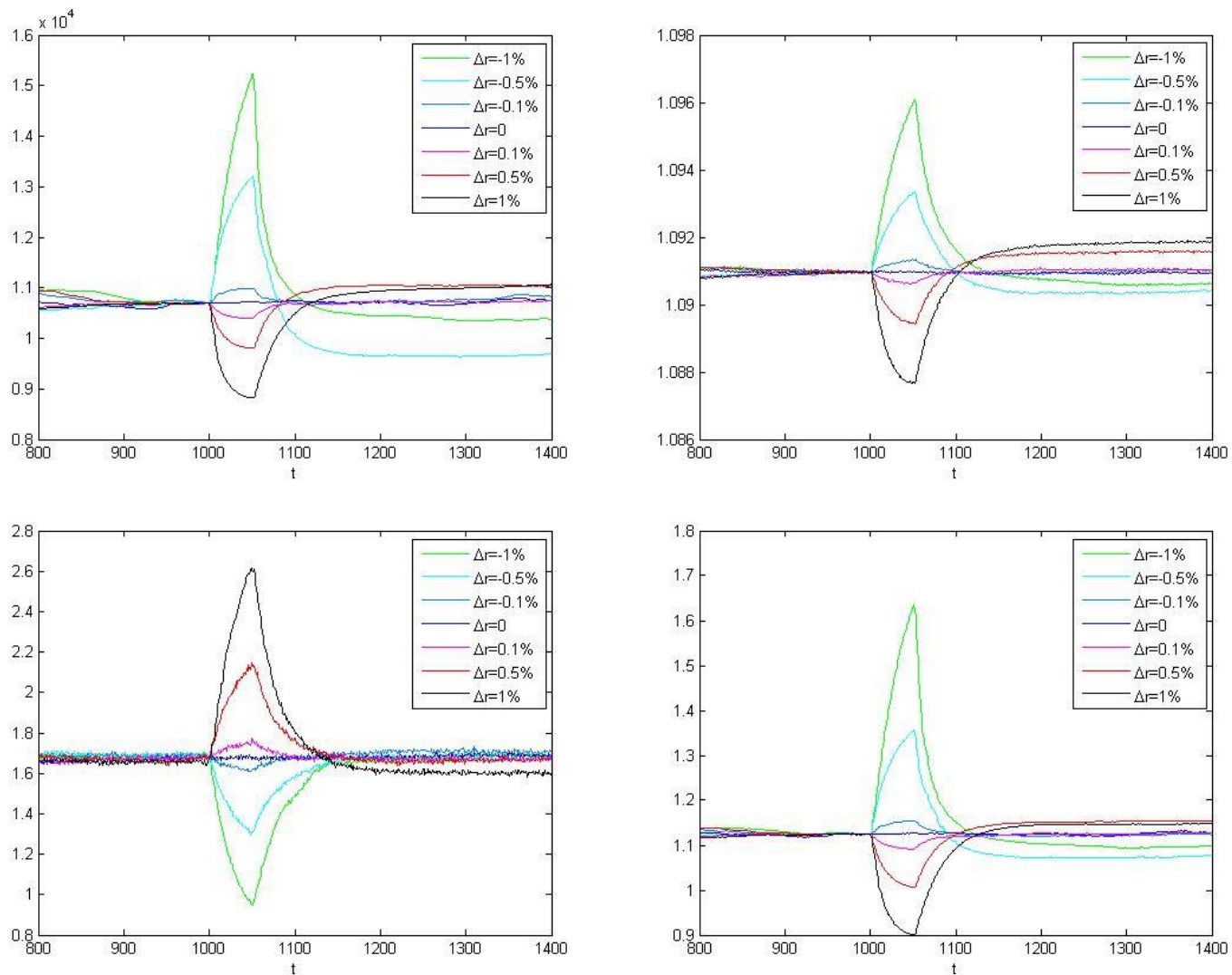

Figure 5: Aggregate real output (up-left), price level (up-right), bad debt-to-total credit (down-left) and leverage (down-right) for various levels of $\Delta r$. Obs.: the variables are normalized to coincide at $\mathrm{t}=1,000$. 

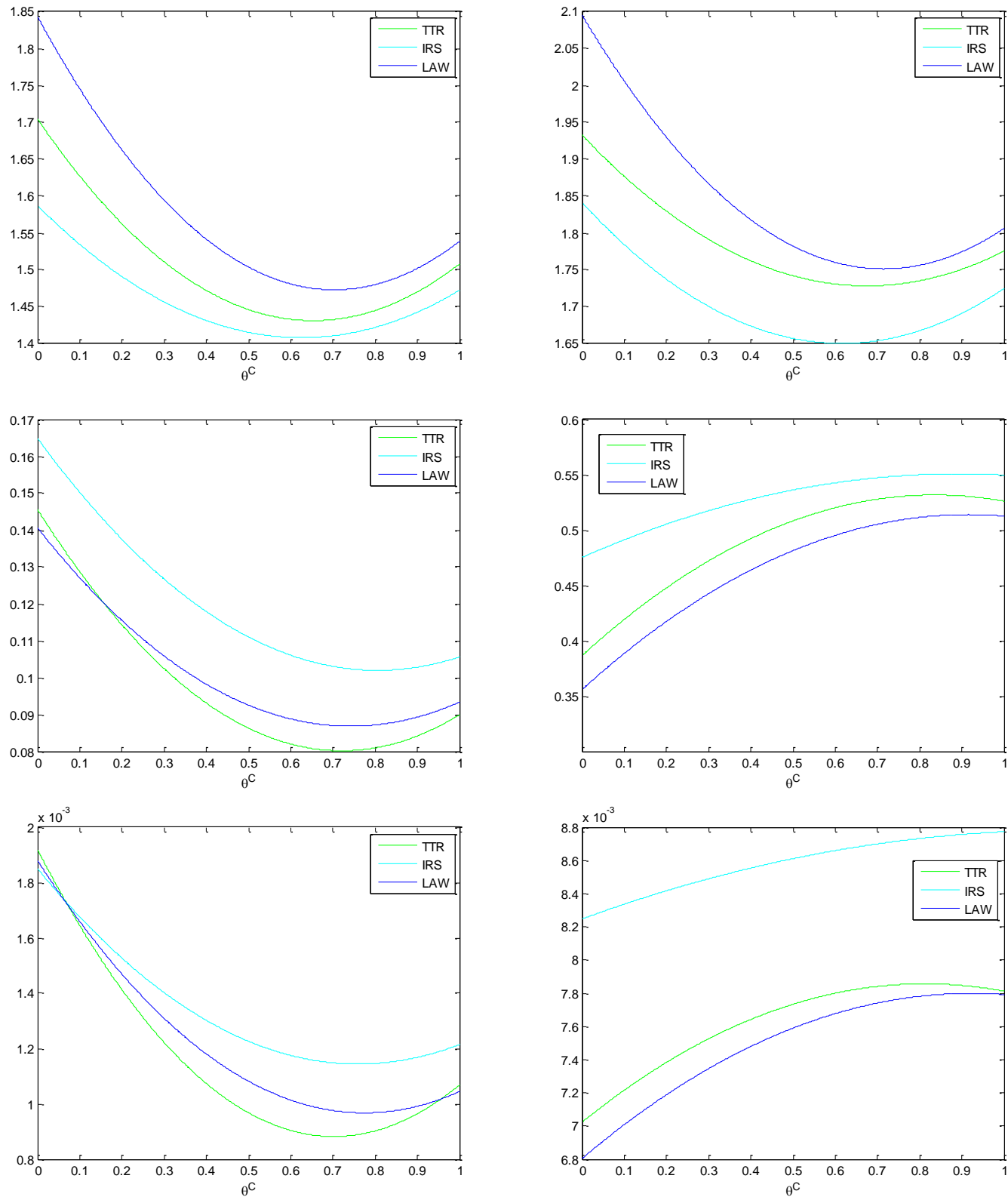

Figure 6: Left: average bad debt-to-credit (top), coefficient of variation of the real output (middle) and coefficient of variation of the price level (down) as functions of $\theta^{\mathrm{C}}$ considering a transient phase comprised by the 200 first periods. Right: the same variables in the no transient period case. 

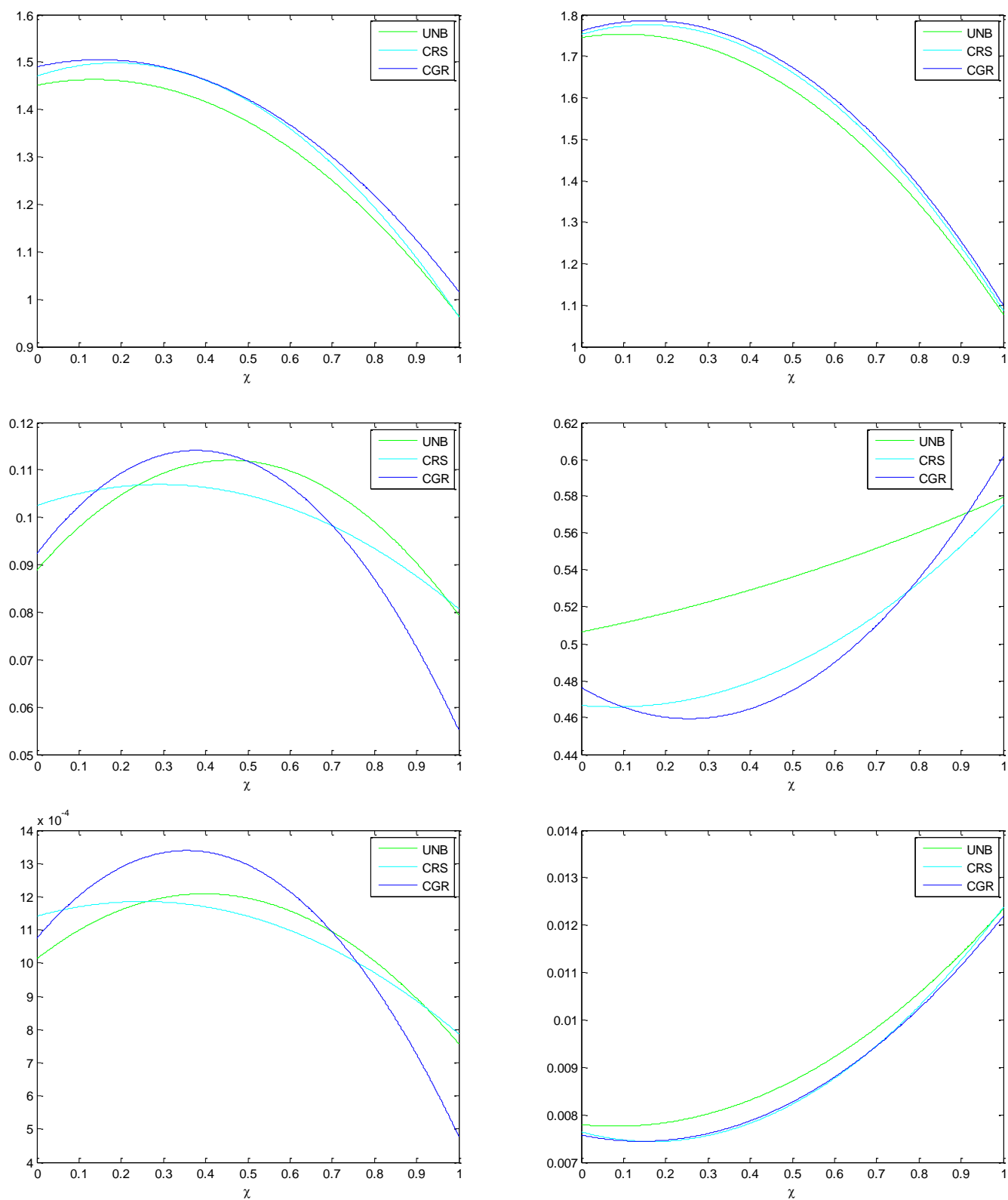

Figure 7: Left: average bad debt-to-credit (top), coefficient of variation of the real output (middle) and coefficient of variation of the price level (down) as functions of $\chi$ considering a transient phase comprised by the 200 first periods. Right: the same variables in the no transient period case. 